\title{
Implementation of Football Sports Extracurricular Activities in SMP Negeri 25 Padang
}

\author{
Siti Khodijah Reza Amum ${ }^{1 *}$ and Nurul Ihsan ${ }^{2}$ \\ ${ }^{I}$ Physical Education, Health and Recreation Department, Faculty of Education and Teachers Training, University of \\ Nusa Cendana \\ ${ }^{2}$ Department of Physical Education, Faculty of Sport Sciences, Padang State University, Padang, Indonesia \\ *Corresponding author. Email: Idahzuba560@gmail.com
}

\begin{abstract}
The purpose of this study was to determine the implementation of extracurricular soccer sports activities at SMP Negeri 25 Padang, including the variable quality of coaches, infrastructure and athlete motivation. The type of this research is descriptive. The research population of all athletes / students participating in soccer extracurricular is 17 people. Sampling is done by total sampling, where all athletes students who take part in the soccer sports extracurricular activities. The research data collection instruments used a questionnaire using the Guttman scale. Data were analyzed with descriptive statistics. Use the formula $\mathrm{P}=$. Data collection of all variables, namely the quality of the trainer, infrastructure, athlete motivation is done by using questionnaire distribution. The data analysis used is descriptive analysis, and conducting interviews and observations. The results of data analysis of the implementation of extracurricular soccer sports activities in SMP Negeri 25 Padang are in sufficient classification.
\end{abstract}

Keywords: Paired Upper Passing Exercises, Volleyball Passing Ability

\section{INTRODUCTION}

Education is one of the fields that plays an important role in developing Indonesian people as a whole. National Education based on Pancasila aims to improve the quality of Indonesian people. It is concluded that national education aims to develop the ability and develop character to educate the nation's life with the aim of developing the potential of students so that they always have faith and devoted to God Almighty, who has noble, physical and spiritual character.

Guidance and development of educational sports ranging from elementary schools to high schools is stated in the Law of the Republic of Indonesia No. 3 (2005: 14), concerning the National sports system: "the coaching and development of educational sports at all levels of education gives freedom to students to carry out sports activities in accordance with their talents and interests". It was concluded that all levels of education direct their students to do sports both in school and outside of school, According to the Ministry of National Education (2003: 3) argues that extracurricular education is based on the Minister of Education and Culture Decree Number 118 / U / 2002 namely "Extracurricular activities are one of the pathways student coaching in addition to the OSIS line of training and leadership as well as widytamandala insight ".

To realize national development, one way to do that is by providing learning and developing talents owned by students. for example in extracurricular activities can be in the form of sports activities that can develop students' ability to achieve achievements in sports and help students in physical education subjects.

In the implementation of extracurricular activities to be carried out properly, According to the Ministry of Education and Culture (2009: 292) explains the steps of carrying out extracurricular activities, namely:

(1) Extracurricular activities given to students individually or in groups are determined by the school based on students' interests, the availability of necessary facilities and the existence of a teacher or officer for that, if the activity requires it, (2) the activities planned to be given to students should be considered for their safety and ability of students as well as local sociocultural conditions.

Based on the descriptions above it can be concluded that schools must be able to manage and carry out extracurricular activities well, planned and coordinated. Extracurricular activities must receive serious attention from the managers of educational institutions with extracurricular activities that can develop student creativity in order to improve achievement in the appropriate sports field. with talent and interest.

Football has been competed since the first Olympics were held. Until now, this sport is still being competed by people on this earth. There have been several soccer matches such as the World Cup, the Olympics, Leagues, and even the regional matches. 
between villages. People are interested in soccer. People are willing to take advantage of the existing field to play soccer even though it does not have a standard FIFA field size.

Playing Soccer aims to score as many goals as possible against opponents. For international field sizes are 100-110 in length and 70-75 in width. This game can be played by anyone who is young or old or male or female, all of whom can play this game. Football is known to have been very long started from the time of the British empire to the present. Indeed, it can be seen that this sport is not boring to be played by everyone.

In this case one of them is through education channels for sports coaching and development, so that something is desired is an achievement. And this is also supported by adequate facilities and infrastructure. Therefore, to foster a culture of sports in order to improve Indonesian people, so that they have a sufficient level of health and fitness starting at an early age through sports education in schools and in the community. Therefore, the development of sports needs to be developed and disseminated throughout all corners of the country in order to socialize sports and develop the community.

The high level of soccer fans in Indonesia has spread to the world of education. Every school should have a football club or soccer extracurricular activities in schools so that the development of students' talents and hobbies can be channeled. These factors are the attention of the school by making professional management in managing the management of a football organization in the school, professional coaches, athletes who excel, facilities and infrastructure are a complete achievement. The attention of the school and the principal and the attention of the parties others support the formation of soccer in school.

The complete requirements factors for coaching soccer in schools can support the coaching of the sport. The existence of good coaching can stimulate students 'enthusiasm in training so that they become outstanding athletes. In addition, this activity can improve students' freshness and fitness at school.

As an alternative to continuing to carry out soccer extracurricular activities, the coaches carry out soccer extracurricular activities outside the school location. Based on the description above it can be concluded that schools must be able to manage and carry out extracurricular activities well, planned and coordinated. In the sense that extracurricular activities must receive special attention from educational institutions in order to enhance and develop students' interests and talents.

Environmental problems, the condition of the soccer field is not good, many students complain and are lazy to practice. In addition to the unfavorable field conditions, there is also the influence of the community in comfort and tranquility in practice. In addition, the field is always crowded with people to play soccer, so students find it very difficult to practice or carry out soccer extracurricular activities.

Based on what the writer pointed out above, the extracurricular activities of the football sport branch in SMP Negeri 25 Padang have not been carried out, it is certainly not good for the development of students, lack of channeled interest, talent and creativity in themselves, so that whatever activities we will carry out will not goes well.

\section{MATERIALS AND METHODS}

The type of research conducted is descriptive of what is happening. This opinion is supported by Notoatmodjo (2012: 135) which states:

"Descriptive research method is a research method carried out with the main objective to make a picture or descriptive of an objective situation. Descriptive research methods are used to solve or answer the problems being faced in the current situation

In accordance with the opinion above, the purpose of this study is to describe how the implementation of extracurricular football sports activities in SMP Negeri 25 Padang.

The place of this research is at SMP Negeri 25 Padang and the place to collect data on the football sports extracurricular activities, namely at the SMA Negeri 2 Padang soccer field. This research is planned to be carried out in February -March 2019.

Data is processed using frequency distribution techniques or descriptive statistics with the following formula:

$\mathrm{P}=\mathrm{x} 100 \%$

Description:

$\mathrm{P}=$ Percentage of answers

$\mathrm{f}=$ Frequency $/$ number of scores

$\mathrm{n}=$ Number of Samples

Source: Usman in Asril (2015: 192)

\section{RESULTS AND DISCUSSION}

Based on the analysis and preparation of data regarding the implementation of extracurricular football sports activities in SMP Negeri 25 Padang, this research chapter will answer the research statement in accordance 
with the formulation of the problems previously proposed, namely:

1. What is the level of professionalism of the

trainers towards the football sports extracurricular activities at SMP Negeri 25 Padang?

2 How complete are the facilities and infrastructure in football sports extracurricular activities at SMP Negeri 25 Padang?

3 What is the motivation of athletes in the implementation of football sports extracurricular activities in SMP Negeri 25 Padang?

For more details the answer to the statement can be described as follows: Overall the level of achievement of the quality of the trainers obtained from 17 respondents for 20 questions is equal to $57.1 \%$, it means that the level of achievement of the quality of the trainers is of sufficient classification. The level of achievement of facilities and infrastructure obtained from 17 respondents for 19 questions is $47.4 \%$, it means that the level of achievement of facilities and infrastructure is of sufficient classification. And for the level of achievement of athlete motivation obtained from 17 respondents for 19 questions is $65.6 \%$, it means that the level of achievement of athlete motivation is in good classification.

Extracurricular activities are additional activities carried out outside school hours with the aim to further develop or broaden students' knowledge and abilities. According to Suharsimi Arikunto in Suryobroto, B. (2009: 287) suggested the definition of extracurricular activities is "additional activities outside the program structure which are generally optional activities". For example sports activities that aim to provide a place for students to channel their potential, interests and talents in the field, this extracurricular activity is very beneficial for students to keep away from negative activities.

Sport is a form of planned and structured physical activity that involves repetitive body movements and is shown to improve physical fitness. According to Zalfendi and Nurul Ihsan (2012: 155) "sport is an advanced form of play and an inseparable part of human daily life. ". With the holding of sports extracurricular activities at school can help students develop their talents and also improve physical fitness in students.

Soccer is an 11-to-11 game that is played on a rectangular field, with the aim of scoring as many goals as possible against the opponent and defending his own goal from the opponent's attack. Football is one of the many sports that is very popular with people in Indonesia and even the entire world community in general. Yulifri (2012: 1) said "football is a sport that is very popular, popular, and loved by all age groups almost all over the world".
For more details, the answer to the statement can be described as follows:

\section{Coach TheThe}

Trainer is someone who is competent and professional in their field. Trainer is a leader or coach for an athlete. The coach has the task to prepare physically, mentally an athlete. The coach plays an important role in the success of an athlete, because the figure of a coach who will shape and prepare an athlete will excel or not in the future.

\section{Facilities and Infrastructure}

Facilities and infrastructure is one of the factors supporting the success of education, sports facilities and infrastructure is one of the supporting factors of achievement in the process of fostering achievement sports. Means are the translation of "Facilities", which is something that is used and utilized in the implementation of sports activities. Sports infrastructure is something that simplifies and streamlines tasks and has a relatively permanent nature. Such as volleyball court, basketball court, soccer field and so on.

\section{Athlete}

Motivation Motivation is the power or driving a person to carry out an activity. Firdaus (2012: 81) adds "motivation can be defined as the driving or driving someone to do something. Motivation has direction and intensity. The direction refers to whether someone is looking for, approaching or interested in certain situation ".

Optimal implementation of sports extracurricular activities in Football will be achieved by understanding an existing problem and a support by several factors including trainers, facilities and infrastructure and adequate motivation of athletes in the exercise to achieve maximum performance.

\section{CONCLUSION AND SUGGESTIONS}

Based on the analysis of the results of the research determined in this study, a conclusion and suggestion can be drawn that the implementation of football sports extracurricular activities at 25 State Junior High Schools in Padang is the level of achievement of coaches in the implementation of football sports extracurricular activities at 25 State Junior High Schools in Padang, amounting to $57.1 \%$. That means it is in theclassification Sufficient.The level of achievement of facilities and infrastructure in the implementation of football sports extracurricular activities in Padang 25 Public Middle School is $47.4 \%$ That means it's in theclassification Enough. The level of achievement in the motivation of athletes in the 
implementation of extracurricular soccer sports activities in SMP Negeri 25 Padang is $65.6 \%$. That means it's in the classification Good.

\section{REFERENCES}

[1] Arsil.2015. Evaluation of Physical Education and Sports.Malang: Wineka Media.

[2] Notoatmodjo,S. 2012. Health Research Methodology.Jakarta: Rineka Cipta.

[3] Suryosubroto.2009.Teaching and Learning Process in Schools.Jakarta: Rineka Cipta.

[4] RI Law No. 3 of 2005 and RI Government Regulation 2007. concerning the National Sports system, Bandung: Citra Umbara.

[5] Yulifri. 2012. Soccer Games. Padang: FIK UNP.

[6] Zalfendi and Nurul Ihsan, 2012.Micro Teaching.Padang: sukabina press. 